Po wstępie autorstwa ks. Jerzego Paszendy SJ, który zajął się również wyborem i redakcją tomu, zamieszczono kilka mapek ilustrujących chronologiczny rozwój sieci szkół jezuickich na ziemiach Rzeczypospolitej oraz spis tychże szkół w porządku chronologicznym i alfabetycznym.

Prace rozpoczynają szkice dotyczące ogólnie szkolnictwa jezuickiego - jego podstawowych zasad (S. Bednarski), nowych elementów wniesionych przez Towarzystwo Jezusowe do szkolnictwa polskiego XVI wieku (L. Piechnik) i wreszcie znany szkic Bronisława Natońskiego nt. szkolnictwa jezuickiego w Polsce w okresie kontrreformacji. Kolejny „blok” poświęcony jest jezuickim seminariom nauczycielskim na ziemiach polskich (B. Natoński, L. Piechnik) oraz alumnatowi wileńskiemu (J. Poplatek).
Następny - jezuickiemu szkolnictwu wyższemu; w tej części znajdujemy obok artykulów poświęconych Akademii Wileńskiej (L. Piechnik), również rozprawy dotyczące projektowanej akademii wojskowej Bartłomieja Wąsowskiego (L. Piechnik), prób przekształcenia braniewskiego kolegium w uniwersytet (L. Piechnik) oraz warszawskiego Collegium Nobilium (L. Piechnik). Na zakończenie zamieszczono szkic dotyczący przemian w szkolnictwie jezuickim w XVIII wieku (L. Piechnik) oraz stosunkowi Towarzystwa do Komisji Edukacji Narodowej (B. Natoński).

Prace uzupełnia bibliografía poświęcona historii szkolnictwa jezuickiego, noty o autorach oraz indeks.

\title{
Publikacje zwarte 1994-1995
}

\begin{abstract}
Akademia Zamojska i jej tradycje, Referaty przygotowane na sesje naukowq zorganizowang dla upamietnienia 400 rocznicy utworzenia przez Jana Zamoyskiego Akademii Zamojskiej, 27 - 28 maja 1994 w Zamościu, red. Szyszka B, Zamość 1994, ss. 147;
\end{abstract}

Album studentów Akademii Zamojskiej 1595-1781, oprac. Gmiterek H., Warszawa 1994, ss. 604;

August Cieszkowski, Wielkopolanin i Europej$c z y k$, pod red. Goryńskiej-Bittner B. i Stepnia J., Poznań 1994, ss. 185;

Bibliografia prac Bogdana Suchodolskiego, Warszawa 1994 , ss. 138 ;

Budzewicz Z, Ksztalcenie literackie w szkolach zawodowych w l. 1918-1939, Kraków 1994, ss. 146;

Górski J. J., Rzecz o Liceum św. Augustyna, Warszawa 1994, ss. 274;

Grzywna J., Guldon Z, Możdżeń S., Podstawy warsztatu historyka oświaty, Przewodnik me- todyczny do prac magisterskich, Kielce 1994, ss. 140 ,

Hausner W., Krakowski skauting 1910-1914, Kraków 1994, ss. 189;

Helena Radlinska - portret pedagoga (rozprawy, wspomnienia, materialy, red. I. Lepalczyk, B. Wasilewska, Lódź 1994 (Folia Paedagogica et Psychologica 34), ss. 230.

Hellwig J., Rola Towarzystwa Naukowej Pomocy im. Karola Marcinkowskiego w awansie spoleczno-zawodowym mlodzieźy polskiej, Poznań 1994, ss. 120;

Hellwig J., Prolegomena do historii wychowanta, Poznań 1995, ss. 124;

Hellwig J., Jamrożek W., Żołądź D., Z prac poznańskich historyków wychowania, Poznań 1994, ss. 142;

Historia wychowania, Skrypt dla studentów studiów dziennych $i$ zaocznych, red. Hellwig J., Poznań 194, ss. 146; 
Historia wychowania. Slownik biograficzny, Olsztyn 1994, ss.142;

Jamrożek W, Idee edukacyjne polskiej socjalnej demokracji w Galicji do 1918 roku, Poznań 1994, ss. 204;

Jaxa-Kwiatkowska B., Profesor Ludwik Jaxa-Bykowski (1881-1948), Ostatnie lata życia, Warszawa 1994, ss. 120;

Karolewicz G., Nauczyciele akademiccy Katolickiego Uniwersytetu Lubelskiego w okresie międzywojennym, Lublin 1994, ss. 322;

Katolicki Uniwersytet Lubelski, Ksiega pamiqtkowa w 75-lecie Katolickiego Uniwersytetu Lubelskiego, Lublin 1994, ss. 828;

Katolicki Uniwersytet Lubelski, 75 lat w slużbie Bogu i Ojczyźnie, Album jubileuszowej wystawy, oprac. Szymik J., Lublin 1994, ss. 110;

Koźmian D., Poglqdy spoleczno-pedagogiczne Aleksandra Kazimierza Patkowskiego (1890-1942), Szczecin 1994, ss. 144;

Ksiega pamiqtkowa 25-lecia Wyższej Szkoly Pedagogicznej w Bydgoszczy, praca zbior. pod red. Jastrzębskiego W., Bydgoszcz 1994, ss. 150 ;

Kupisiewicz C., Koncepcje reform szkolnych w latach osiemdziesiatych, Warszawa 1994, ss. 152 ;

Marek Z., Rozwój teorii religijnego wychowania dziecka $w$ wieku przedszkolnym $w$ Polsce $w$ latach 1945 -1990, Kraków 1994, ss. 351;

Michalska I., Czasopisma Zwiazku Nauczycielstwa Polskiego dla dzieci w okresie Drugiej Rzeczypospolitej, Lódź 1994, ss. 193;

Michalska I., Michalski G., Wychowanie przez teatr szkolny w II Rzeczypospolitej, Warszawa 1994, ss. 126;

Michalski G, Zygmunt Myslakowski (1890 - 1971), dzialalność i twórczość pedagogiczna, Lódź 1994, s. 152;

Michalski S., Praca naukowo-badawcza nauczycieli w Drugiej Rzeczypospolitej, Poznań 1994, ss. 190;

$\mathrm{Na}$ przelomie. Wspomnienia nauczycieli i uczniów z lat 1944 - 1956, Wybór i oprac. Król E. C., Walczak M., Warszawa 1994, ss. 390;
Od wieków ksztalci pasterzy, Wyższe Seminarium Duchowne we Woclawku, zespół red. Bagrowicz J. $i$ in., Włoclawek 1994, ss. 115;

Organizacja i funkcjonowanie wspólczesnych systemów edukacyjnych, wyb. i oprac. Gumuła T., Krasuski J., Majewski S., Kielce 1994, cz. I - ss. 275 , cz. II - ss. 252, cz. III - ss. 160 ;

Pitala A., Kolegium Pijarów w Krakowie, Kraków 1994, ss. 274;

"Podkowiacy", Wychowankowie Państwowego Gimnazjum im. Stefana Batorego w Warszawie, oprac. Leśniewski A. i Kujawski E., Warszawa 1994, ss. 261;

Skowronek J., Mlodzież polska $i$ jej organizacje w ruchu narodowym 1795-1864, Warszawa 1994, ss. 88;

Slownik biograficzny katolicyzmu spolecznego, Lublin 1994, t. 1 (A-J) - ss. 201, t. 2 (K-P)-s. 218;

Smolalski A., Idealy wychowawcze w polskiej myśli pedagogicznej od $X И$ wieku do końca II Rzeczypospolitej, Opole 1994, ss. 88;

Socha J., Dzialalność Centralnego Towarzystwa Rolniczego $w$ dziedzinie oświaty rolniczej 1907 -1929, Lódź 1994, ss. 148;

Stopka K., Szkoly katedralne metropolii gnieznieńskiej w średniowieczu. Studia nad ksztalceniem kleru polskiego w wiekach średnich, $\mathrm{Kra}$ ków 1994, ss. 274;

Studia $z$ dziejów edukacji, wybór Miąso J., Warszawa 1994, ss. 356;

Sztobryn S., Filozofia wychowania Sergiusza Hessena, Lódź 1994, ss. 223;

Teksty źródlowe do dziejów wychowania, wyb. i oprac. S. I. Możdżeń, cz. 6: Wiek XIX $i$ poczqtek XX, Kielce 1994, ss. 155; cz. 7: Ważniejsze prady $i$ koncepcje wychowawcze $w$ pedagogice I p. XX w., Kielce 1994, ss. 92; cz. 8: Szkolnictwo w Polsce 1918-1945, Kielce 1994, ss. 97;

Winiarz A, Zwiqzek Harcerstwa Polskiego na Lubelszczyźnie 1918 -1939, Lublin 1994, ss. 180;

Wychowanie $w$ rodzinie. Od starożytności po wiek XX, pod red. J. Jundziłła, Bydgoszcz 1994, ss. 496;

Z dziejów szkolnictwa jezuickiego w Polsce, Kraków 1994, ss. 260. 